\title{
SEPLENANGAN DALAM UPACARA KABUMI DI DESA WATUAJI KECAMATAN KELING KABUPATEN JEPARA
}

\author{
Cintya Berlianisa Smaranada \\ Program Studi S1-Etnomusikologi ISI Yogyakarta \\ E-mail: cintyaberlianisas@gmail.com
}

\begin{abstract}
Abstrak
Upacara kabumi merupakan upacara sejenis bersih desa yang digunakan untuk mrngungkapkan rasa syukur kepada Tuhan atas hasil bumi yang dilimpahkan kepada masyarakat. Pada upacara kabumi di Desa Watuaji, terdapat prosesi seplenangan yang dilaksanakan pada hari Senin Legi pukul 12.00 WIB. Prosesi seplenangan adalah prosesi berupa mengarak makanan untuk dipersembahkan kepada petinggi dan perangkat desa lainnya. Prosesi seplenangan dipimpin oleh cucuk lampah dan diiringi dengan Gending Seplenangan. Dilihat dari bentuk penyajiannya, gending ini dibunyikan secara terus menerus sampai prosesi seplenangan selesai. Gending yang dimainkan secara berulang-ulang tersebut mengandung makna. Makna Gending Seplenangan dibedah menggunakan teori semiosis karya Charles Sanders Peirce dengan metode penelitian kualitatif dan pendekatan etnomusikologis. Teori semiosis karya Peirce berupa relasi triadik yang terdiri dari representamen, objek, dan interpretan. Berdasarkan relasi triadik Peirce, terdapat tiga makna yang dihasilkan dari Gending Seplenangan. Makna tersebut antara lain makna ikonik, makna indeksikal, dan makna simbolik.
\end{abstract}

Kata kunci: seplenangan, Gending Seplenangan, upacara kabumi, Desa Watuaji, bentuk penyajian, makna.

\begin{abstract}
Kabumi ceremony is ceremony that celebrated in village. The event as the form of thanks for God as the blessing that gave into society. The kabumi ceremony that located at Watuaji Village, there is will be found seplenangan that hold on Monday Legi at 12.00 PM. Seplenangan is a procession of presented food for high person in Watuaji Village. Seplenangan procession led by cucuk lampah and accompanied with Gending Seplenangan. Seen from the form of performances, Gending Seplenangan is played continuosly until the procession is done. The gending that play continuosly has a meaning. The meaning of the Gending Seplenangan using semiosis theory from Charles Sanders Peirce with qualitative research method and ethnomusicological approach. Semiosis theory by Peirce is triadic relation consists of representament, object, and interpretant. Based on Peirce triadic relation, there are three meaning that produce by Gending Seplenangan. The meaning as follows iconic meaning, indexical meaning, and symbolic meaning.
\end{abstract}

Keyword: seplenangan, Gending Seplenangan, kabumi ceremony, Watuaji Village, form of performances, the meaning. 


\section{A. Latar Belakang}

Desa Watuaji merupakan desa yang terletak di Kecamatan Keling. Desa ini merupakan desa yang pernah didatangi oleh para wali dan ulama pada tahun 1465 Masehi, salah satunya ialah Syech Maulana Ahmad Husain. Syech Maulana Ahmad Husain beserta ulama lainnya yang mendatangi desa tersebut mempunyai tugas, yaitu menyebarkan agama Islam kepada masyarakat Desa Watuaji. Selama melakukan tugas, Syech Maulana Ahmad Husain wafat di Desa Watuaji, dan kemudian dimakamkan di Dukuh Brengkel (www.desawatuaji.blogspot.com, 10 Oktober 2019). Dari penyebaran agama Islam yang dilakukan oleh beliau, seluruh masyarakat Desa Watuaji akhirnya memeluk agama Islam. Sampai saat ini, penduduk Desa Watuaji baik penduduk asli maupun pendatang seluruhnya adalah pemeluk agama Islam.

Masyarakat Desa Watuaji yang mayoritas berprofesi sebagai petani, sangat menghormati Syech Maulana Ahmad Husain atas jasanya yang sudah mengenalkan dan menyebarkan agama Islam kepada mereka. Mereka menghormati beliau dengan cara mengunjungi makam beliau serta membaca doa-doa untuk beliau. Biasanya mereka berkunjung atau ziarah ke makam tersebut di saat-saat tertentu, salah satunya adalah saat upacara kabumi.

Upacara kabumi merupakan sejenis upacara bersih desa yang dilaksanakan setiap tahun untuk mengucap syukur kepada Tuhan atas hasil bumi yang telah dilimpahkan kepada masyarakat. Alasan upacara tersebut dilakukan karena mayoritas masyarakatnya berprofesi sebagai petani yang berhubungan dengan hasil panen berikutnya. Selain berziarah di makam Syech Maulana Ahmad Husain, pada upacara kabumi juga terdapat sebuah prosesi yang dianggap masyarakat sebagai puncak dari upacara kabumi. Prosesi yang dimaksud ialah prosesi seplenangan.

Prosesi seplenangan adalah prosesi berupa mengarak makanan untuk dipersembahkan kepada petinggi dan perangkat desa lainnya. Petinggi adalah sebutan yang digunakan oleh masyarakat sekitar untuk menyebut kepala desa. Prosesi seplenangan dipimpin oleh seorang cucuk lampah, kemudian diikuti oleh beberapa orang di belakangnya sesuai jumlah makanan yang akan diarak. Cucuk lampah merupakan orang yang ditugaskan untuk memimpin upacara kabumi, khususnya pada prosesi-prosesi tertentu sesuai dengan apa yang dilakukan oleh cucuk lampah sebelumnya.

Prosesi seplenangan diiringi dengan Gending Seplenangan. Gending ini digunakan sebagai pengiring ketika cucuk 
lampah mengarak makanan dengan gerakan langkah kaki yang sudah ditentukan secara turun temurun.

Hal menarik yang terdapat pada Gending Seplenangan adalah bentuk penyajiannya yang unik, yakni harus dimainkan atau dibunyikan pada pukul 12.00 WIB bersamaan dengan jalannya prosesi seplenangan hingga prosesi seplenangan berakhir. Selain itu, pada gending tersebut terdapat bunyi dhengklek yang berada di penghujung gending untuk berkomunikasi kepada cucuk lampah bahwa instrumen gong akan dibunyikan untuk mengakhiri notasi gending dan kembali ke notasi awal. Gending ini dimainkan secara terus menerus sampai prosesi seplenangan selesai. Keunikan dari Gending Seplenangan yang sudah dijelaskan tersebut belum pernah diteliti oleh siapapun, sehingga sangat penting untuk diadakan penelitian mengenai bentuk penyajian sebuah Gending Seplenangan.

Fakta yang ada di lapangan menunjukkan, bahwa upacara kabumi di Desa Watuaji selalu disertai dengan Gending Seplenangan. Hal ini menimbulkan dugaan bahwa Gending Seplenangan mengandung makna tertentu pada prosesi seplenangan. Namun demikian, makna yang terdapat pada Gending Seplenangan belum diketahui oleh masyarakat luas termasuk masyarakat Desa Watuaji. Hal ini dapat dibuktikan dari anggapan beberapa warga, salah satunya adalah Marsini. Marsini mengatakan bahwa dia tidak mengetahui makna dari Gending Seplenangan, karena dia hanya mengetahui Gending Seplenangan adalah salah satu syarat untuk prosesi seplenangan (Marsini, tukang adang. 13 Desember 2019).

Penelitian ini difokuskan pada bentuk penyajian serta makna dari Gending Seplenangan. Hal ini dikarenakan bentuk penyajian dan makna dari Gending Seplenangan belum diketahui oleh masyarakat umum.

Teori yang digunakan untuk membedah makna gending tersebut adalah teori semiosis karya Charles Sanders Peirce. Teori ini berupa relasi triadik antara representamen, objek, dan interpretan.

\section{B. Metode Penelitian}

Untuk menemukan jawaban rumusan masalah pada penelitian ini, perlu digunakan berbagai metode serta pendekatan yang tepat. Tujuan dari penggunaan metode ataupun pendekatan adalah untuk membedah berbagai fenomena yang terdapat dalam masyarakat. Salah satu fenomena yang diambil dalam penulisan ini ialah fenomena musik dalam sebuah konteks tertentu. Dengan demikian, metode dan pendekatan yang tepat digunakan penelitian ini adalah metode penelitian kualitatif dan pendekatan etnomusikologis. Metode penelitian 
kualitatif adalah metode untuk mengeksplorasi dan memahami makna yang dianggap berasal dari masalah sosial atau kemanusiaan (Creswell, 2017: 5). Penjelasan tentang pendekatan etnomusikologis akan dijelaskan pada poin di bawah ini.

\section{Pendekatan}

Menurut Shin Nakagawa, yang dilakukan dalam menerapkan pendekatan etnomusikologis adalah melihat objek penelitian melalui teks dan konteks (2000: 6). Pada studi etnomusikologi, musik tidak cukup diamati sebagai kejadian akustik saja seperti melodi (lagu), ritme, tempo, warna nada (tone colour), dan lainlain, tetapi juga dihubungkan dengan masalah kemasyarakatannya atau dihubungkan dengan suasana yang dibentuk oleh masyarakat pendukung musik tersebut (2000:6).

\section{Teknik Pengumpulan Data}

a. Studi Pustaka

Studi pustaka mengenai prosesi seplenangan dan upacara kabumi dilakukan di Perpustakaan UPT ISI Yogyakarta, Perpustakaan Daerah Kabupaten Jepara, Perpustakaan Pusat UGM, Perpustakaan Grhatama, dan Perpustakaan Kota Yogyakarta. b. Observasi

Observasi dalam penelitian kualitatif adalah observasi yang dilakukan oleh peneliti dengan langsung terjun ke lapangan untuk mengamati perilaku serta aktivitas individu-individu di lokasi penelitian (Creswell, 2017: 267). Pada penelitian ini, observasi yang dilakukan yaitu terjun langsung ke lapangan untuk mengamati seluruh rangkaian upacara kabumi di Desa Watuaji. Observasi dalam penelitian ini, dilaksanakan pada tanggal 14 Agustus 2017, 24 Januari 2019, 8 Juli 2019, 9 Juli 2019, 10 Juli 2019, 11 Juli 2019, 12 Juli 2019, 13 Juli 2019, 14 Juli 2019, dan 15 Juli 2019.

\section{c. Wawancara}

Istilah wawancara dalam penelitian kualitatif adalah wawancara yang dilakukan oleh peneliti dengan cara melakukan face-to-face interview atau wawancara berhadap-hadapan dengan partisipan, mewawancarai mereka dengan telepon, atau terlibat dalam focus group interview yang terdiri dari enam sampai delapan orang di setiap kelompoknya (Creswell, 2017: 267). Wawancara yang dilakukan dalam penelitian ini, yaitu wawancara kepada warga Desa Watuaji, khususnya warga yang berperan dalam upacara kabumi. 
d. Dokumentasi

Dokumentasi dalam sebuah penelitian dilakukan untuk pengumpulan data secara visual, audio, dan audio visual yang terdapat pada upacara kabumi 2019 mulai dari hari pertama hingga hari terakhir pelaksanaan upacara.

\section{Analisis Data}

Analisis data merupakan proses yang membutuhkan refleksi terus menerus terhadap data, mengajukan pertanyaanpertanyaan analitis, dan menulis catatan singkat sepanjang penelitian (Creswell, 2017: 274). Setelah semua data terkumpul, data tersebut dipilih untuk dianalisis dan difokuskan kepada pokok permasalahan dalam penelitian. Setelah itu, dilakukan pembedahan data menggunakan teori yang sudah dipilih dengan metode deskriptif analisis serta pendekatan etnomusikologis.

\section{Hasil dan Pembahasan}

Bagian ini akan dijelaskan bentuk penyajian dan makna dari Gending Seplenangan. Bentuk penyajian Gending Seplenangan dibagi menjadi dua golongan, yaitu bentuk penyajian secara musikal dan bentuk penyajian secara non-musikal. Bagian yang membahas makna Gending Seplenangan akan dianalisis menggunakan teori semiotik yang dikembangkan oleh Charles Sander Peirce.
1. Bentuk Penyajian Gending Seplenangan

a. Bentuk penyajian musikal

Bentuk penyajian musikal terdiri dari instrumen yang digunakan, irama, laya, tabuhan atau lagu, laras, pathet, dan padang ulihan.

Instrumen yang digunakan adalah instrumen gamelan Jawa yang terdiri dari gong, kempul, kethuk, kenong, kendang ciblon, kendang ageng, gender, slenthem, saron demung, saron barung, saron penerus atau peking, bonang barung, dan bonang penerus. Instrumen-instrumen tersebut ditabuh menggunakan tabuhan gaya Surakarta.

Irama yang digunakan pada Gending Seplenangan yaitu irama dados. Irama adalah satuan waktu yang dipakai untuk menyajikan gending (Soetandyo, 2002: 55). Kata irama dados berarti irama dadi, yaitu setiap sabetan berisi empat pukulan saron penerus.

Laya yang digunakan dalam Gending Seplenangan yaitu wilambita laya yang artinya tempo lambat. Laya adalah cepat atau lambatnya tempo di dalam istilah karawitan (Martopangrawit, 1975: 2). Laya digolongkan menjadi tiga jenis, yaitu druta laya (tempo cepat), madya laya (tempo sedang), wilambita laya (tempo lambat). Jenis wilambita laya yang dipakai pada Gending Seplenangan bertujuan untuk membentuk rasa khidmat seorang cucuk 
lampah dalam menjalankan prosesi seplenangan, karena mempersembahkan sesuatu tidak perlu tergesa-gesa.

Lagu adalah susunan nada-nada yang diatur dan apabila dibunyikan sudah terdengar enak. Pengaturan nada-nada tersebut akan berkembang ke suatu bentuk, dan bentuk inilah yang disebut gending (Martopangrawit, 1975: 3). Pada Gending Seplenangan, bentuk gending yang paling tepat ialah bentuk ketawang. Dapat dikatakan ketawang, karena pada gending ini terdapat tabuhan instrumen kolotomis bentuk ketawang. Adapun ciri-ciri dari bentuk ketawang, yaitu gending berukuran pendek, dalam satu gong terdiri atas dua kenongan, satu kenongan berisi dua gatra, dan gong dibunyikan pada akhir gatra keempat bersama kenong (Soetandyo, 2002: 37). Di bawah ini merupakan notasi dari Gending Seplenangan.

$\begin{array}{lllllllllll}2 & 1 & 2 & 1 & 2 & 2 & 1 & 2 & 5 & \overline{65} & .5\end{array}$

$\begin{array}{lllllllllllllll}12 & 1 & 6 & 2 & 1 & 6 & 5 & 1 & 2 & 1 & 6 & 2 & 1 & 6 & (5)\end{array}$

Laras yang digunakan pada Gending Seplenangan yaitu laras slendro. Berikut adalah susunan nada laras slendro.

$$
\begin{array}{cccccc}
1 & 2 & 3 & 5 & 6 & \text { 1 } \\
J i & \text { ro } & \text { lu } & \text { ma } & \text { nem } j i
\end{array}
$$$$
\begin{array}{llllll}
3 & 5 & 6 & \dot{1} & \dot{2} & \dot{3}
\end{array}
$$$$
\text { Mi Sol La Do Re Mi }
$$

Pada Gending Seplenangan, laras yang digunakan adalah laras slendro pathet sanga. Hal ini dikatakan pathet sanga, karena gending ini mempunyai ciri-ciri yang sama dengan ciri-ciri pathet sanga. Ciri-ciri tersebut antara lain, terdapat nadanada yang berat, yaitu nada 5, 1, dan 2, sedangkan nada 6 dan 3 hanya sebagai nada rangkaian (Mardimin, 1991: 37). Selain itu, pathet sanga ialah pathet ber-“dong" nada 5 serta jatuh di gong 5. Meskipun sebagian besar pathet sanga mempunyai gong nada 5, beberapa gending pathet sanga juga mempunyai gong selain 5 .

Padang ulihan merupakan semacam kalimat tanya dan kalimat jawab jika dalam musik barat. Istilah padang merupakan bagian kalimat lagu yang berada di depan, sedangkan istilah ulihan merupakan bagian kalimat lagu yang berada di belakang (Soetandyo, 2002: 103). Panjang pendeknya padang ulihan dalam sebuah gending, tergantung pada bentuk gending itu sendiri, karena setiap gending mempunyai peraturan sendiri-sendiri. Padang ulihan yang terdapat pada Gending Seplenangan adalah padang ulihan gending ketawang. Berikut merupakan notasi Gending Seplenangan yang sudah diberi keterangan padang ulihan.

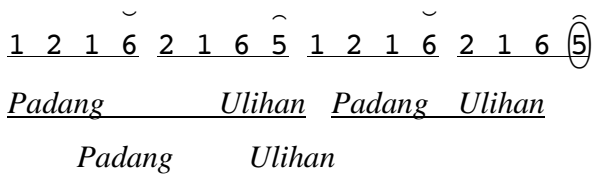


Dilihat dari notasi setiap kalimat, notasi yang diulang sama persis dengan kalimat sebelumnya. Hal tersebut menjadikan gending ini tidak mempunyai padang ulihan. Meskipun terdapat pengulangan notasi, kalimat padang dan kalimat ulihan pada gending tersebut dapat ditentukan sesuai instrumen kolotomis. Pada kalimat padang terdapat pukulan instrumen kenong yang berada di balungan keempat gatra kedua, sedangkan pada kalimat ulihan terdapat pukulan instrumen gong yang berada di balungan keempat gatra keempat yang merupakan bagian akhir dari bentuk ketawang.

b. Bentuk penyajian non-musikal

Bentuk penyajian Gending Seplenangan secara non-musikal terdiri dari pelaku, kostum, dan tata letak. Pelaku dalam penyajian Gending Seplenangan pada prosesi seplenangan adalah penabuh itu sendiri dan soundman beserta crew mic yang mengoperasikan sound system, microphone, dan segala macam kabel. Jumlah anggota penabuh adalah 8 orang, sedangkan jumlah orang yang mengurus sound system adalah 3 orang. Penabuh atau pengiring prosesi seplenangan berasal dari kelompok gamelan Desa Cepogo, Kecamatan Kembang.

Kostum yang dikenakan oleh pengiring seplenangan adalah pakaian sehari-hari. Ada yang memakai kaos, dan ada pula yang memakai kemeja batik atau kemeja casual. Kostum pengiring tidak begitu penting, karena yang lebih penting adalah mengiringi seplenangan dari awal hingga akhir, lagipula yang lebih pantas dilihat adalah cucuk lampah yang harus menggunakan kostum (Suroto, 10 Januari 2019).

Letak pengiring prosesi dan letak pelaku prosesi dipisah. Letak pengiring prosesi berada di halaman rumah petinggi dan menggunakan panggung. Letak prosesi seplenangan dilakukan di dalam rumah petinggi. Dilakukan secara terpisah, karena luas ruangan dan kedua pertunjukan tersebut tidak memungkinkan untuk disatukan. Selain itu, alasan dilakukan secara terpisah adalah ruangan prosesi adalah ruang tamu rumah petinggi. Tidak mungkin jika pengiring dan pelaku prosesi berada dalam satu ruangan yang sama, karena ruang tamu dalam rumah petinggi sudah dipenuhi oleh perangkat desa, tamu undangan, dan tokoh-tokoh masyarakat Desa Watuaji untuk menunggu sekaligus menyaksikan seplenangan.

2. Makna Gending Seplenangan

Menurut I Wayan Senen dalam bukunya yang berjudul Bunyi-bunyian dalam Upacara Keagamaan Hindu di Bali,

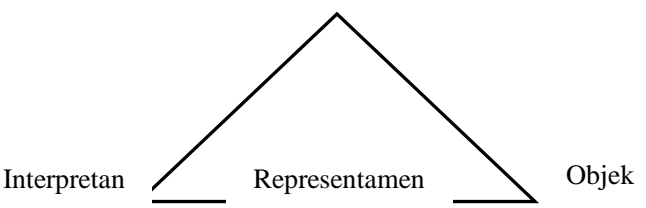


untuk menganalisis makna bunyi-bunyian dalam upacara keagamaan dan upacara kebudayaan dapat digunakan teori semiotik Charles Sanders Peirce dengan proses tahapan semiosis ROI yang dikaitkan dengan bentuk ikon, indeks, dan simbolik (2015: 213).

Peirce menyebut sebuah tanda sebagai representamen (R), konsep, benda, ataupun gagasan yang diacunya sebagai objek $(\mathrm{O})$, dan makna (impresi, kogitasi, perasaan, dan seterusnya) yang diperoleh dari sebuah tanda diberi istilah interpretan (I). Tiga dimensi ini selalu hadir dalam signifikasi. Oleh karena itu, Peirce memandang sebagai sebuah struktur triadik (Danesi, 2011: 32). Berikut merupakan struktur triadik dari Peirce.

Pada penyajian Gending Seplenangan, hubungan antara Representamen (R), Objek (O), dan Interpretan (I), diibaratkan seperti bunyi gending sebagai Representamen (R), suasana atau karakter gending, gotong royong, prosesi seplenangan dikatakan sebagai Objek (O), dan tujuan penyajian gending dikatakan sebagai Interpretan (I). Teori semiosis Peirce ini dikaitkan dengan bentuk ikon, indeks, dan simbol. Makna semiotik dari ikon, indeks, dan simbol dalam bunyi Gending Seplenangan dianalisis melalui proses semiosis Representamen (R), Objek (O), dan Interpretan (I). a. Makna Ikonik Gending Seplenangan

Makna ikonik dari Gending Seplenangan digambarkan melalui pola tabuhan instrumennya, khususnya pola tabuhan kontrapung. Dengan demikian, masing-masing penabuh satu sama lain memiliki tanggung jawab atau tugas sendiri-sendiri. Setiap penabuh wajib memperhatikan tugas tabuhannya sesuai kerangka penyajian instrumen secara keseluruhan dan dibawakan sesuai dengan konsep garap dari Gending Seplenangan. Hal ini berarti bahwa para penabuh diharapkan mampu mewujudkan kerja sama yang bagus dalam pola tabuhan pada suatu gending dan menjaga keseimbangan tabuhan yang baik antar penabuh. Kegiatan seperti menabuh gamelan sama dengan kegiatan gotong royong dalam masyarakat. Gotong royong merupakan bekerja bersama untuk mencapai suatu tujuan yang sama pula. Selain gotong royong yang digambarkan pada para penabuh gamelan, gotong royong juga dapat digambarkan pada prosesi seplenangan. Semua warga desa yang berpartisipasi dalam prosesi tersebut juga mempunyai tugas masingmasing. Contohnya seperti cucuk lampah yang bertugas mengiringi selama prosesi seplenangan berlangsung, dan lain sebagainya.

Fenomena ini menunjukkan bahwa terdapat hubungan ikonik antara penyajian gending dengan kegiatan gotong royong 
pada prosesi seplenangan. Penyajian dari Gending Seplenangan dapat diposisikan representamen $(\mathrm{R})$, dan kegiatan gotong royong prosesi seplenangan adalah objeknya (O). Dari hubungan ikonik antara representamen $(\mathrm{R})$ dan objek $(\mathrm{O})$ tersebut dapat diinterpresentasikan bahwa penyajian dari Gending Seplenangan mengandung

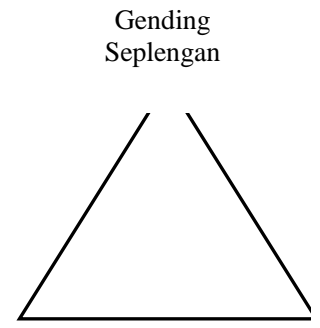

Ketenangan dan kesabaran (I)

makna damai, ketentraman, toleransi, saling menghargai satu sama lain, dan lain sebagainya.

b. Makna Indeksikal Gending Seplenangan

Makna indeksikal yaitu sifat Gotong

(O)

kausalitas yang menunjuk kepada tanda hubungan representamen dan objek. Makna indeksial Gending Seplenangan digambarkan dengan pemakaian gending dalam prosesi seplenangan. Gending ini dipakai untuk iringan seplenangan. Selain digunakan sebagai iringan, gending ini juga dibutuhkan sebagai pembentuk suasana dari prosesi itu sendiri. Oleh karena itu, tidak ada prosesi seplenangan yang diiringi dengan gending lain selain Gending
Seplenangan. Gending Seplenangan wajib dimainkan pada saat prosesi tersebut dimulai. Dengan demikian, dapat diketahui bahwa kehadiran Gending Seplenangan disebabkan karena terselenggaranya prosesi seplenangan.

Dari kehadiran gending ini, sudah jelas bahwa penyajian dari Gending Seplenangan sebagai iringan merupakan representamen, sementara prosesi seplenangan yang dikatakan sebagai objek (O) adalah penyebab hadirnya gending tersebut. Hubungan representamen dan objek yang sudah dijelaskan ini menimbulkan suasana yang dibentuk oleh prosesi seplenangan. Suasana yang dibentuk, suasana tenang dan sabar. Ketenangan dan kesabaran yang dibentuk oleh prosesi seplenangan dipandang interpretan.

\section{c. Makna Simbolik Gending Seplenangan \\ Simbol merupakan tanda yang} representamen dan objeknya didasari oleh konvensi sosial atau kesepakatan. Secara parsial (himpunan nada), gending juga banyak mengandung makna simbolik. Contohnya adalah pemberian makna simbolik pada Gending Seplenangan yang terdiri dari tiga bagian: buka sebagai introduksi awal, lagu sebagai bagian pokok, dan suwuk sebagai akhir dari gending. 
Secara proses semiosis, bunyi Gending Seplenangan yang disajikan dalam prosesi

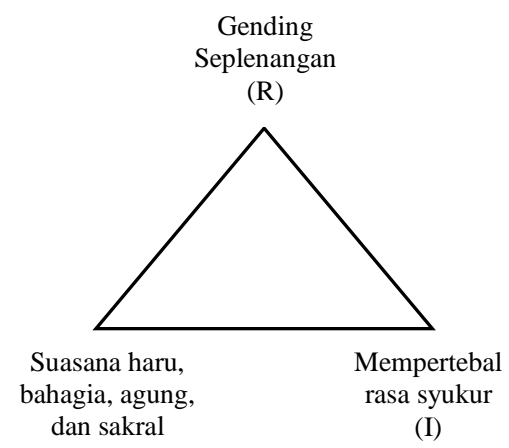

(O)

dikatakan sebagai representamen (R).

Dilihat dari jalinan melodinya, Gending tersebut memiliki suasana yang campur aduk, baik itu bersifat haru bahagia maupun agung dan sakral (Suwanto, cucuk lampah. 26 Desember 2019). Suasana dari bunyi Gending Seplenangan inilah yang menjadi objek (O). Berdasarkan hubungan dari representamen dan objek, dapat diinterpretasikan (I) bahwa bunyi Gending Seplenangan mengandung makna simbolik yang sifatnya meningkatkan rasa syukur, karena pada saat prosesi ini dilaksanakan, suasana tersebut dapat mendorong, memunculkan dan mempertebal rasa syukur para peserta atas kelancaran yang sudah diberikan oleh Tuhan kepada hambanya untuk melaksanakan upacara kabumi, sehingga suasana prosesi menjadi lebih khidmat dan khusyuk.

\section{Simpulan}

Prosesi seplenangan yaitu prosesi berupa mengarak makanan yang dipersembahkan untuk petinggi dan perangkat desa lainnya dengan diiringi Gending Seplenangan. Gending Seplenangan yang hanya dimainkan saat prosesi seplenangan tersebut mempunyai keunikan, yaitu Gending Seplenangan dibunyikan secara terus menerus atau diulang-ulang sampai prosesi seplenangan selesai dan gending tersebut diselesaikan tanpa suwuk yang melambat.

Gending yang dibunyikan secara terus menerus dalam prosesi seplenangan mengandung makna. Makna bunyi Gending Seplenangan tersebut dapat dibedah menggunakan teori semiotik karya Charles Sanders Peirce. Teori ini mengajarkan untuk membedah makna dari sebuah fenomena dengan proses tahapan semiosis ROI yang dikaitkan dengan ikonik, indeksikal, dan simbolik. Makna ikonik Gending Seplenangan adalah ketentraman, toleransi, dan saling menghargai. Makna indeksikal Gending Seplenangan berupa ketenangan dan kesabaran. Makna simbolik Gending Seplenangan yaitu peningkatan rasa syukur.

\section{E. Daftar Pustaka}

Buchler, Justus. 1955. Philosophical Writing of Peirce. New York: Dover Publications, Inc.

Creswell, John W. 2017. Research Design: Pendekatan Kualitatif, Kuantitatif, dan Mixed. Yogyakarta: Pustaka Pelajar. 
Danesi, Marcel. 2011. Pesan, Tanda, dan Makna: Buku Teks Dasar Mengenai Semiotika dan Teori Komunikasi. Yogyakarta: Jalasutra.

Mardimin, Yohanes. 1991. Belajar Karawitan Dasar. Semarang: Satya Wacana.

Martopangrawit. $1975 . \quad$ Catatan Pengetahuan Karawitan I. Surakarta: ASKI Surakarta.

Nakagawa, Shin. 2000. Musik dan Kosmos: Sebuah Pengantar Etnomusikologi. Jakarta: Yayasan Obor Indonesia.

Pangrawit, D. Dwija. Bombong Manah: Tuntutan Karawitan Jawi. Surakarta: Cendrawasih.

Prayitna, Hendra dan M. Abi Tofani. tt. Buku Pinter Basa Jawa Pepak. Surabaya: Karya Utama.

Putra, SW. Biman. 1994. Kumpulan Gendhing-Gendhing Lan Lagon Dolanan. Surakarta: Cendrawasih.

Smaranada, Cintya Berlianisa. 2020. "Seplenangan dalam Upacara Kabumi di Desa Watuaji Kecamatan Keling Kabupaten Jepara”. Skripsi untuk menempuh derajat Strata 1 Program Studi Etnomusikologi Jurusan Etnomusikologi Fakultas Seni Pertunjukan Institut Seni Indonesia Yogyakarta.

Senen, I Wayan. 2015. Bunyi-bunyian dalam Upacara Keagamaan Hindu di Bali. Yogyakarta: Badan Penerbit ISI Yogyakarta.

Soetandyo. 2002. Kamus Istilah Karawitan. Jakarta: Wedatama Widya Sastra.

Sumarto. 1983. Buku Karawitan Gaya Baru Jilid 1 untuk Sekolah Menengah Pertama. Solo: Tiga Serangkai.

Supanggah, Rahayu. 2002. Bothekan Karawitan I. Jakarta: Masyarakat Seni Pertunjukan Indonesia. . 2009. Bothekan Karawitan II: Garap. Surakarta: Program Pascasarjana bekerja sama dengan ISI Press Surakarta. 